Li Tsziun'zhu (2015) Novaia paradigma upravleniia KPK. Chzhetszian, Izd-vo pravitel'stva provintsii Chzhetszian. 453 p. (In Chinese).

Van Iuitao (2009) Sbornik agitatsionnykb plakatov «60 let istorii Kitaia». Gonkong, Izdatel'stvo OOO «Khepin tu shu». 144 p. (In Chinese).

U Khunlian (2018) Issledovanie ideologicheskoi paradigmy KPK «Chelovek v osnove vsego» na rannem etape realizatsii. Khunan', Narodnoe izd-vo Khunan'. 233 p. (In Chinese).

Submission date: 19.07.2019.

Ишутина Юлия Александровна - кандидат культурологии, доцент кафедры китаеведения Восточного института - Школы региональных и международных исследований, докторант Аепартамента искусств и дизайна Школы искусств и гуманитарных наук Аальневосточного федерального университета. Адрес: 690002, Россия, г. Владивосток, Океанский пр-т, д. 108-120. Tел.: +7 (914) 970-53-85. Эл. аapec: ishutina.yua@dvfu.ru

Ishutina Yulia Aleksandrovna, Candidate of Culturology, Associate Professor, Department of Sinology, Oriental Institute - School of Regional and International Studies, Doctoral Student, Department of Arts and Design, School of Arts and Humanities, Far Eastern Federal University. Postal address: 108-120, Okeansky Ave., Vladivostok, Russian Federation, 690002. Tel.: +7 (914) 970-53-85. E-mail: ishutina.yua@dvfu.ru

DOI: $10.17805 /$ zpu.2020.1.11

\title{
Современный мир и противоречия религиозной комМУнИКатИвности
}

\author{
В. Л. АМЕЛЬЧЕНКОВ (ЕПИСКОП СЕРАФИМ) \\ СИНОДАЛЬНЫЙ ОТДЕЛ ПО ДЕЛАМ МОЛОДЕЖИ РУССКОЙ ПРАВОСЛАВНОЙ ЦЕРКВИ; \\ РОССИЙСКИЙ ГОСУДАРСТВЕННЫЙ СОЦИАЛЬНЫЙ УНИВЕРСИТЕТ
}

Статья посвящена осмыслению религиозных коммуникаций как частного случая культурной коммуникации, уровень протекания которой затрагивает специализированную область конфессиональной практики. Цель исследования: представить религиозные коммуникации в виде системы, актуализировав противоречивое единство ее составляющих в глобализирующемся мире. Выделены следующие группы противоречий религиозных коммуникаций: сущностные, акцидентные, специфические. Сущностные противоречия демонстрируют момент их сохранения, что подчеркивает структурные коллизии и инаковость конфессий. Насущным становится переход от «столкновения» к конструктивной встрече и взаимопониманию. Акцидентные противоречия высвечивают возможность дискурсивных течений в устоявшихся религиозных убеждениях. Использование социальных сетей и информационно-коммуникационных технологий трансформирует формообразующее обрамление религиозной коммуникации. Специфические противоречия обозначают метаморфозу системы религиозных коммуникаций, перестройку ее средств. Смена стадии технологического развития инициировала диверсифицированность коммуникативных стратегий Церкви. Ограниченный информационный локус Русской Православной Церкви сменился ее широкоформатным позиционированием в социокультурном пространстве.

Ключевые слова: культура; религия; Церковь; коммуникативная культура; религиозная коммуникация 
ВВЕАЕНИЕ

Последние два десятилетия, ознаменованные перманентной технологической 1 революцией, все чаще называют «эпохой цифры», которая коренным образом изменила содержание и формы коммуницирования людей. Многослойность современных коммуникаций - от традиционной, «глаза в глаза» до технологичной, гаджетной - высвечивает синусоидность развития с колебательными движениями вперед и откатами назад (Ремизов, 2017). Возникший особый тип культуры информационного общества - медиакультура(Сапунов, 2006) - становится посредником между обществом и государством, социумом и властью. Более того, целые системы виртуальных взаимосвязей стирают границы, предоставляя людям свободу по отношению к морали. Выступая первопринципом социума, коммуникация сегодня превращается в ключевой механизм культуры. В этот процесс оказываются втянутыми религиозные институты, коммуницирование которых изначально сопряжено с сакральной первоосновой (Гриненко, 2000). Аанный процесс трансформируется, в нем формируются сегменты гегемонии различных массмедиа. Религиозная коммуникация есть частный случай культурной коммуникации, уровень протекания которой затрагивает специализированную область конфессиональной практики. Это процесс передачи и обмена информацией религиозного содержания посредством знаково-символической системы, подразумевающий наличие определенных субъектов и возникающей между ними связи.

Здесь важно подчеркнуть, что развитие любого процесса предопределено противоречиями - наличием взаимоисключающих сторон, явлений в их внутреннем единстве. Как известно, их разрешение приводит к основным типам изменений: «мутациям» количественно-качественного порядка; структурным коллизиям; метаморфозным перестановкам; «удержаниям противоречий». Последний тип инициирует парадоксальность противоречий, в частности религиозных коммуникаций.

Представляется, что развитие религиозных коммуникаций, детерминируемых в первую очередь духовными и социокультурными реалиями, можно показать в виде системы, которая являет собой проекцию общего процесса коммуницирования на религиозную сферу. Можно выделить следующие группы противоречий: сущностные, акцидентные, специфические.

Цель данного исследования - представить религиозные коммуникации в виде системы, актуализировав противоречивое единство ее составляющих в глобализирующемся мире.

\section{СУЩНОСТНЫЕ ПРОТИВОРЕЧИЯ РЕАИГИОЗНЫХ КОММУНИКАЦИЙ}

Эти противоречия, имеющие место на протяжении всего времени существования мировых религий, воспроизводят характер их взаимоотношений и вскрывают сущность процесса религиозной коммуникации.

1. Противоречие между глобальным сближением культур, провозглашаемой нетерпимостью к конфликтам на разных уровнях и несовместимостью доктринальных воззрений представителей разных конфессий.

Объявленное ЮНЕСКО Международное десятилетие сближения культур (до 2022 г.), призванное оградить грядущие поколения от бедствий войны и содействовать социальному прогрессу, фиксирует зыбкость современных реалий. Отчетливо обнаружимые разновекторные сценарии перехода из установившегося мира в турбулентное состояние и наоборот позволяют представить сближение культур как «мно- 
гомерный, нелинейный процесс с маятниковыми колебаниями, точками пересечения, бифуркационными тупиками» (Ирхен, 2014: 254). Провозглашенная идеологема о сближении культур побуждает к взаимопониманию и обоюдному ознакомлению с культурным, этническим, языковым и религиозным разнообразием.

Разнопорядковая включенность культур в глобализационные процессы и возникающее непонимание между западноевропейскими и восточными культурами обусловлено «темпоральной рассогласованностью, неравномерностью общественного развития» (Костина, 2011:12). Здесь можно согласиться с мнением о том, что традиционные «закрытые» нехристианские культуры с преобладанием аграрного хозяйства, религиозно-мифологического мышления и систем устной коммуникации наименее приспособлены к диалогу с другими общностями современных и постсовременных культур (там же). Более того, попытки интеграции и внедрения доминирующей идеологемы приводят к обособлению в культурные анклавы.

Известно, наиболее сложными и напряженными во всем мире были и остаются взаимодействия между христианством и исламом, что обусловлено позиционированием разных картин мира. Православные и католики в большей степени ориентированы на диалог, что в целом закономерно, с учетом формирования культур на общем фундаменте христианских ценностей. Между тем во взаимоотношениях Польши и России, например, исторически наблюдаются диаметральные конвергенции: от общественно-политических до конфессиональных и культурологических. Представляется, что первым шагом снижения градуса политической напряженности между Польшей и Россией можно считать «Совместное послание народам России и Польши Патриарха Московского и всея Руси Кирилла и Председателя Епископской Конференции Польши Архиепископа Юзефа Михалика» (2012 г.). Его ключевая интенция базируется на пастырском призыве к примирению от лица двух Церквей к населению своих стран - католическому в Польше и православному в России. С учетом внешнеполитической напряженности между странами представляется значимым не только продолжение контактов между Римско-Католической Церковью в Польше и Русской Православной Церковью, но их поступательное движение, готовность совместно отвечать на социальные вызовы (Амельченков, 2015). Аичное участие автора в составе официальной делегации Московского Патриархата во Всемирных днях молодежи в Кракове в 2016 г., общение с польскими иерархами, представителями политической элиты, польской молодежью подтверждает отсутствие непреодолимых барьеров между культурами.

Аействительно, история Церкви запечатлела немало примеров, когда иерархи оказывались неким «мостом примирения» между двумя народами. Речь идет о выдающемся общественном деятеле, филантропе XX в. священномученике Серафиме (Остроумове), архиепископе Смоленском, имя которого неразрывно связано с судьбами Православной Церкви в Польше (Холмском крае) и России (Москве, Орловской и Смоленской областях). Разделяя суровые испытания для Церкви и народов обеих стран, социальная забота архипастыря распространялась на все население безотносительно его религиозной и национальной принадлежности (Biskup Serafin (Amielczenkow), 2019). Иерарх видел свою миссию в том числе в налаживании взаимопонимания восточной и западной цивилизаций. Поддержание пастырской переписки с друзьями и духовными чадами из Польши в условиях большевистского режима 1920-1930-х гг. стало поводом для абсурдных обвинений его в антисоветской деятельности, принадлежности к фашистской организации. Все это приводит к вы- 
воду о том, что в личности священномученика архиепископа Серафима (Остроумова) поляки и россияне имеют крепкий «мост примирения». Культивация его религиозно-культурного наследия может стимулировать, говоря словами М. М. Бахтина, «диалог разностей на почве общего» (Бахтин, 1975). В данном случае «инаковость» есть конституирующий элемент межхристианского диалога. Исходя из этого посыла можно утверждать, что процесс сближения не сводится к искоренению доктринальных разногласий. Обсуждаемая в современном католическом теологическом дискурсе идея тринитарности в диалоге допускает многообразие и различие, достижение межконфессиональной целостности посредством архетипа триединства.

Несмотря на это, обобщенный взгляд на глобальное сближение культур в реалиях обнаруживает культурное соперничество, скрытое столкновение религий, инициирующее угрозу возникновения культурных войн в разных регионах мира.

2. Противоречие между христианским экуменизмом и дифференииачией духовной жизни этносов, государств, общностей.

Экуменическое движение, возникшее в началеХX в., стремится найти основу для взаимопонимания различных конфессиональных традиций. Ключевое для католического экуменизма понятие «единство в многообразии» приобретает конкретные формы в социокультурном экуменизме, главный результат которого знаменует конец разобщенности и разрозненности народов. Однако идея обретения христианского единства, преодоления межконфессиональной раздробленности в дискурсе нередко подвергается критике, ибо православный мир стоит на незыблемости доктрины веры периода Вселенских Соборов и не принимает введения новых догматов, от которых католики и протестантыне готовы отступиться.

С позиций всемирно-исторического процесса глобализация многих сторон жизни человечества еще только начинается, впереди - изменение ее векторов, корректировка форм, углубление воздействий на сложившийся миропорядок. При этом, как представляется, многие народы и сообщества способны согласовывать универсальные жизненные параметры с определяющими ценностно-смысловыми основаниями национальной культуры. Сочетание локальных различий с особенностями транснациональной системы связей и отношений, именуемое глокализацией, дифференцирует духовную жизнь этносов, общностей.

Известно, что идея глобального, изначально корреспондирующая с социологией религии, придает религиозный нюанс самому концепту «глобализация». При этом выкристаллизовывается понимание религии в глобальном порядке не только как институции, анклава, общины, но прежде всего «некоего жанра коллективной или индивидуальной идентичности» (Robertson, Chirico, 1985: 229). В России идея универсализации изначально «апеллировала не столько к государственно-политическому, правовому объединению людей, сколько к их единству в вере и духе (соборность)» (Межуев, 2012: 339; курсив наш. - B. А.). Неслучайно российская идентичность, сформировавшись как Святая Русь, с ее «народом-богоносием», защитником православного идеала, сопряжена с ценностно-нормативной составляющей культуры, в основе которой лежит православие. Православная Церковь в своем экуменическом дискурсе стоит на позиции того, что для абсолютного и наивысшего единства всех христиан, осуществляемого в Таинстве Евхаристии, необходимо принятие всеми христианскими конфессиями вероучения древней неразделенной Церкви эпохи Вселенских Соборов. Между тем на пути к этой весьма сложной цели Православная Церковь считает полезным и необходимым взаимодействие с инославными конфес- 
сиями в социальной, культурной и гуманитарной сферах, а также совместное отстаивание традиционных евангельских ценностей и моральных норм в современном секулярном обществе.

Следует отметить, что дифференциация как составная часть закона неравномерности развития общества кристаллизуется вокруг ценностной составляющей. В современных реалиях дифференциация духовной жизни региональных сообществ просматривается, с одной стороны, по линии этнической культуры, плотно сцепленной с формами хозяйствования, нормами повседневной культуры, бытовыми привычками, обычаями, обрядами, местным диалектом. При этом этническое разнообразие коррелирует с густонаселенными городскими агломерациями. С Аругой стороны, обособления этносов и обществ сопрягаются с конфессиональными измерениями. Стабилизируя в целом общественные отношения, религия может оказывать двоякое воздействие на этнокультурную идентичность, размывая либо укрепляя ее - «где нет ни Еллина, ни Иудея, ни обрезания, ни необрезания, варвара, Скифа, раба, свободного, но все и во всем - Христос» (Кол. 3:11). При әтом, что вполне закономерно, национальный и религиозный факторы оказываются приоритетными при идентификации приверженцев ислама. Учитывая полиэтничный и поликонфессиональный состав населения России, представляется важным укрепление коммуникативных связей среди граждан страны.

Следовательно, идеологема «единство в многообразии» объясняет дробление религиозных систем, равно как и их стремление к поиску единого, что можно рассматривать как совмещение локального и глобального.

\section{АКЦИАЕНТНЫЕ ПРОТИВОРЕЧИЯ РЕАИГИОЗНЫХ КОММУНИКАЦИЙ}

Акцидентные (косвенные) противоречия порождаются глубинными разногласиями и всецело от них зависят.

1. Противоречие между императивностью библейских норм, традииионных церковных установлений и современными практиками повседневной культурь.

В век высоких технологий общество априори пользуется благами цивилизации, которые опираются на научные достижения: высокий уровень жизненного комфорта, свободу передвижения в мировом культурном пространстве, омолаживание организма, поддержание здоровья и пр. Возросшая средняя продолжительность жизни, наличие прижизненных видеозаписей и фотографий, на которых человек по-прежнему жив после своей физической смерти, - все это позволяет обрести «информационное бессмертие». К тому же возможности информационно-коммуникационных технологий позволяют оставлять после себя видеообращения и послания в будущее с предписанным временем просмотра, чтобы родственники таким способом могли поддерживать некий контакт с усопшими. Безусловно, в таком мире представляется затруднительным найти место для Христа, ибо цивилизация позволяет ни о чем не беспокоиться. В результате православие как система веры и социальных воззрений, исторически формирующих массовое сознание, нередко смещается на периферию общественной жизни, в сферу приватных убеждений.

Несомненно, культура общества потребления с ее мирскими соблазнами притупляет духовный взор людей, побуждая смотреть на все только плотским оком. Реагируя на Бога довольно скептически, современный человек зачастую не склонен устанавливать с Ним личный контакт, а введенные Церковью установления воспринимает в качестве некоего рудимента, пережитка прошлого. Это позволяет говорить 
о том, что повседневная практика современного человека слабо коррелирует с закрепленными в Священном Писании смыслами.

Религиозные философы, духовные деятели определяют подлинный религиозный опыт через интенцию на главное, через воспринимаемые личностью Божественные предметы жизни. «Заполняя душу своими содержаниями, они пронизывают ее до дна своими лучами, слагают в ней новые акты и новую жизнь и возвратно излучаются из нее в мир» (Ильин, 2002: 271). Человеческая природа, поврежденная грехом, испытывает постоянную потребность в благодатных символах Божественного присутствия в повседневности. Эту функцию выполняют иконы и другие священные предметы и символы, являясь для современного человека окном в духовный мир. Молитва перед образом Спасителя подвигает к всецелому приятию Его евангельского учения; обращение к образам Пресвятой Богородицы и святых угодников апеллирует к эталонным моральным и культурным нормам. Здесь произведение изобразительного искусства выступает «знаковым посредником в пространстве идеального (репрезентативного) отношения человека и Абсолюта» (Жуковский, Пивоваров, Копцева, 2006:111).

Сегодня каждый человек знает о существовании Евангелия, при этом немногие обращаются к Божественному Слову в обыденной культуре. Ааже в дни Великого поста, когда Церковь особо акцентирует необходимость покаяния, мир оставляет без должного внимания искупительный подвиг Сына Божиего. Отсутствие личного религиозного опыта и непонимание необходимости духовного очищения приводит к доминированию в повседневных культурных практиках неглавных измерений, отсутствию так называемой «ценностной лествицы». Выстраивая отношения с другими «не из главного», человек колеблется между смирением и гордыней, миролюбием и деспотизмом, теряет духовно-нравственную составляющую социального бытия, что выливается в «утрату культурой своей сущностной функции - быть ориентиром и критерием развития общества и человека» (Абдулатипов, 2012: 89). Восприятие социального бытия без интенции на главное устремляет человека к бездуховности.

В теологической и светской трактовке духовность понимается на уровне общего подхода идентично: как нравственная саморефлексия личности с «внутренним человеком», что представляет содержательный тезаурус индивидуализированных ценностей (Ремизов, 1997). Приобщение народа к религии, активной церковной жизни вовсе не означает автоматической фиксации духовности личности. Вполне возможно, что бездуховностьустремится к конъюнктурным религиозным практикам, к внешнему духовному практицизму, нарочитой причастности к православию. Это не имеет ничего общего с духовным богатством личности.

В современных реалиях, когда в массовом сознании и поведении наблюдается противопоставление религиозной и частной жизни, а личность обретает возможность свободы на уровне целеполагания, анализа ситуаций, выбор в пользу традиционных установок жизнедеятельности представляется выбором культурной и религиозной идентичности. И здесь справедливо мнение о том, что “"новые русские”, “новые американцы”, “новые немцы” и др. олицетворяют язычество, выступающее реакцией на трепетную духовность христианской культуры со всей ее небесной ностальгией» (Панарин, 2002: 490). Собственно, разбалансированность личного и социального религиозного опыта определяет ряд других характеристик религиозной коммуникации. 
2. Противоречие между (нео)языческими рудиментами и православием как системой.

Неоязычество как культурно-религиозный феномен обращено к дохристианскому уровню бытия культуры, возрождению языческих норм. Зародившись в религиозной сфере, язычество культивирует политеистическое начало, преклонение перед пантеоном богов. В современном массовом обществе можно наблюдать его трансформацию в обожествление вещей, культ потребления, фетишизацию «золотого тельца», в результате чего деньги становятся всеобщим эквивалентом всего Сущего. Возрождающееся неоязычество под видом призыва к архаике, неразрывному единству человека и природы преследует определенные мировоззренческие установки, которые служат угрозой потери нравственности отдельной личностью и целыми сообществами, ибо насаждается зло и насилие, языческое отношение к телесности, утверждается агрессивность в межличностных отношениях.

Аля православия и русской культуры в целом неоязычество предстает эпатажным и одновременно опасным явлением, некой деструкцией культуры, которая, сегрегируя общество на сильных и слабых, достойных и недостойных, утверждает идею национального обособления, что в конечном счете оборачивается утратой идентичности на всех уровнях. В условиях активации партнерства со странами Востока прогнозируется наращивание неоязыческих практик от восточных религиозных культурных традиций (индуизма, буддизма, шаманизма). Поэтому православная вера как «культурный код», ценностно-смысловая матрица русской культуры, объединяя народ, мотивирует его к практике духовных идеалов, к опыту постижения свободы и утверждения достоинства, позволяет преодолеть дикость и невежество, характерные для (нео)языческой парадигмы.

Таким образом, (нео)языческие рудименты и их возрождение в современных реалиях вступают в противоречие с православием как системой через духовные смыслы бытия, непохожесть ментальных характеристик, уровень культурных форм.

\section{СПЕЦИФИЧЕСКИЕ ПРОТИВОРЕЧИЯ РЕАИГИОЗНЫХ КОММУНИКАЦИЙ}

Представляется, что в развитии религиозных коммуникаций можно также выделить специфическую группу противоречий, отражающую дихотомию «технизация - антропологизация».

1. Противоречие между динамичностью религиозных коммуникаиий и установкой на религиозную каноничность.

Об этом противоречии, ярко проступающем в глобализационных реалиях, еще в 1906 г. писал философ-богослов протоиерей С. Н. Булгаков. Редукция понятия Церкви до церкви-храма стала, по его мнению, основной причиной сужения сфер ее влияния. Между тем при наличии неподвижной мистической основы в лице своего Божественного Главы и истинного догматического учения о Нем, Церковь есть живой организм, творящий, растущий, исторически развивающийся во времени и пространстве... «церковь-человечество, церковь-культура, церковь-общественность» (Булгаков, 2018: 10-11). Результатом такого понимания должно стать возрождение церковной жизни на основе свободного общения и соборного творчества. В современной России продуцирование Церковью социальных проектов оказывается альтернативой гражданским инициативам.

Как известно, присущее православию неизменное сохранение церковной догматики и религиозной традиции придает духовную субстанцию ментальным свойствам 
русского народа. Отсюда исключительная точность соблюдения религиозных обрядов, порядка богослужебной практики и священнодействия, атрибутивные составляющие которого (церковные песнопения, молитвословия, иконопись) могут побуждать человека обращаться к духовно-мистической первооснове.

Идущие из глубины веков христианские традиции существуют как вполне самостоятельные явления, как часть культурной картины мира. Эти традиции можно представить в двух ипостасях: носителем высокой духовности, ценностно-смысловой матрицы и одновременно гарантом социокультурной устойчивости сообществ.

Известно, что в культуре в равной степени неприемлем как замкнутый на прошлом традиционализм, так и оторванный от своих корней модернизм. Нынешние реалии демонстрируют трансформацию отдельных религиозных традиций со стороны протестантских конфессий: введение женского священства и епископата, признание однополых союзов и др.

Утрата численности паствы инициирует выработку иной идеологемы, поскольку новые ожидания человека становятся вызовом времени. В этой связи Римско-Католическая Церковь на II Ватиканском соборе (1962-1965 гг.) допустила возможность совершения богослужений не только на латыни, но и на современных национальных языках как одинаково спасительных для народа. Это позволяет рассматривать трансформацию религиозной традиции как развитие ее внешней формы при сохранении неизменяемости вероучительной доктрины.

Русская Православная Церковь, несмотря на присущий ей традиционализм, также допускает совершение богослужений и литургических действий на современных языках. Это дает основание говорить о подвижности формы религиозной традиции и устойчивости ее внутреннего наполнения, играющего регулятивную роль и сохраняющего особый символический смысл. С одной стороны, традициология в горизонте религиозной коммуникации обеспечивает внутреннюю гомогенность, культурную преемственность, наследование и консервацию сакральных смыслов; с другой - налицо адаптация канонического содержания к современным социокультурным реалиям.

2. Противоречие между массовидной природой Божественной литургии и ее индивидуальной периепиией и апперцепщией.

Это противоречие исходит из соотношения параметров общего и личного в литургии, понимания ее смысла как «общего дела» церковной общины - священников и мирян.

Массовидность литургии обусловлена первостепенностью соборности, универсальностью самого «Таинства Царства», ибо всем молящимся здесь и сейчас дается возможность духовно преобразиться, пережить внутреннее обновление. Характерно, что сплоченность вокруг «общего дела» - любви к Богу, встречи с Ним - побуждает человека жертвовать личными интересами, свободным временем и оставлять свои житейские заботы. Совершаемая в пространственно-временном континууме Евхаристия остается константной по своей сути. Получив свое начало на Тайной Вечере, она из сионской горницы устремилась во все точки земного шара и совершается по сей день. В этом смысле Божественная литургия есть священнодействие вселенского масштаба, в котором и проявляется глубинная сущность Церкви.

Происходящее на литургии инициирует особое психодуховное состояние личности, которое приводит к естественно имманентным ассоциациям, сознание формирует внутренние картины «реальности». Безусловно, это состояние, определяемое- 
степенью воцерковленности, концентрацией внимания, пониманием языка и погружением в смысл происходящего действия, носит сугубо индивидуализированный характер.

В теологическом дискурсе Божественная литургия предстает «великим символическим действием», «собранием Неба и земли» с присутствующим сонмом святых (Григорий, 2001: 49). Так, например, агиографические повествования полны сюжетов о том, как святым подвижникам (святителю Спиридону Тримифунтскому, преподобному Сергию Радонежскому и др.) за совершаемой ими литургией сослужили ангелы. Явление небесных свидетелей, по утверждению священника П. Флоренского, отображается в иконостасе, который и есть сами святые (Флоренский, 2004: 441-442). И хотя для большинства молящихся мистическое существо литургии остается незримым, соучастие в священнодействии позволяет человеку отрешиться от земной суеты, достигнуть умиротворения, устремиться к Творцу и живому общению с Ним. Возникающая религиозная коммуникация в определенном смысле отражает духовные настроения, глубину веры каждого, что, по утверждению В. Франкла, означает переход «не к универсальной, а к личной, глубочайшим образом персонализированной религиозности, с помощью которой каждый сможет общаться с Богом на своем собственном, личном, интимном языке» (Франкл, 1990: 336-337). Фактически философ в качестве единицы церковной жизни рассматривает верующего индивида с присущим ему духовным опытом.

Между тем на богослужении «личное» преломляется исключительно через «общее». Ааже практикуемые сугубые молитвословия (прошения) по просьбе отдельно взятого человека предстают делом всей общины. Совершаемое в конце литургии, как ее венец, Принятие Святых Христовых Таинств означает всеобщее единение, причастие всей Церкви. Наконец, массовидность Божественной литургии, как источника духовной жизни и надежды, можно обнаружить в широком спектре общественно-просветительских действий прихожан - всего того, что именуется «литургией после литургии». Это распространение веры, утверждение искренней любви, выражение благодарности Богу, культивирование добра и милосердия.

Следовательно, массовидная природа Божественной литургии заложена в самой ее сути, как феномена общинности, «общего дела». И хотя восприятие богослужения, его воздействие на ум и сердце человека индивидуально, каждый участвует в нем как член церковной общины.

3. Противоречие между технологичностью "гаджетовой» религиозной коммуникативности и антропологической природой общения.

Следствием высокого уровня медиатизированности современного общества становится включение всемирной сети Интернет в орбиту явлений религиозного порядка. Активное использование Церковью и священнослужителями спутниковых связей, гаджетов последнего поколения обусловливает «сакрализацию» виртуальной реальности в виде нормы повседневной культуры.

Аостаточно вспомнить появление «кошерного» поисковика Koogle с отсутствующими ссылками на нежелательный, с точки зрения иудаизма, контент; или отвечающую нормам шариата социальную сеть для мусульман Salamworld; специально составленные молитвы для чтения перед выходом во всемирную сеть. Аля верующих людей веб-страницы выступают неким информационным фильтром. Роль Интернета для человеческого знания не подлежит сомнению. Римско-Католическая Церковь даже провозгласила святого Исидора Севильского покровителем Интернета. Все 
это дает основание говорить, что через освоение ранее светских социальных ниш религия становится медиумом социокультурных процессов.

Как известно, ядром технологического способа производства выступают такие взаимосвязанные направления развития техники и технологий, как микроэлектроника, биотехнология, информатика. Последняя определяет информатизацию всех сторон жизнедеятельности, начиная от трудовой и заканчивая созданием виртуального мира. Согласно прогнозам зарубежных футурологов, к середине нынешнего века технизация социума дополнится внутренней технизацией самого человека, биологически несовершенные органы которого будут заменяться искусственными. Более того, физические, технологически непосредственные, «живые» контакты между людьми станут редкостью, а сам субъект «растворится» в әлектронных сетях (Kurzweil, 1999).

В традиционных религиозных коммуникациях технологичность обусловливает стандартизацию, недостаточную мобильность форм, стиля, жанров. Можно наблюдать и технологическую опосредованность обратной связи в системе «коммуникатор - реципиент».

В то же время привлечение медиаресурсов позволяет религиозным организациям активно информировать о своей деятельности. Так, за последнее десятилетие (2009-2019 гг.) сделано многое для развития системы освещения православной церковной тематики в российских массмедиа. Созданный в 2009 г. Синодальный отдел по взаимоотношениям Церкви с обществом и средствами массовой информации призван формировать единую информационную политику Русской Православной Церкви, налаживать взаимодействие с православными и светскими СМИ. Аостаточно отметить, что к началу 2019 г. созданы официальные сайты всех епархий Московского Патриархата, 206 страниц епархий в социальной сети «ВКонтакте»; 140 страниц епархий в социальной сети «Фейсбук». Остальные епархии имеют страницы в обеих или хотя бы в одной из двух социальных сетей. Активно начинает развиваться присутствие епархий и приходов, а также священнослужителей в социальной сети «Инстаграм» и в мессенджерах 1 . Осваивая новые типы коммуникаций посредством современных информационных технологий, Церковь включается в интернетпроекты. И хотя первопроходцем Рунета в этом направлении стал протестантский проект «Христианская афиша»с картой протестантских церквей, следует отметить и православный интернет-проект «Глобус Митрополии», где собраны биографические сведения о православных священниках, информация о культовых организациях Санкт-Петербурга и Аенинградской области².

Однако «гаджетовое» насыщение повседневной жизни представляет не только угрозу для конфиденциальности, но и стимулирует появление виртуальной зависимости. Возможности тотального точечного контроля над личностью, согласно христианским позициям, знаменуют «предвестие пришествия Антихриста». Об этом неоднократно говорил Патриарх Московский и всея Руси Кирил ${ }^{3}$. Кроме того, «гаджетовая»коммуникативность, используя технику невербалики весьма специфичным образом, может негативно отразиться на межличностных отношениях в социуме.

В противовес технологизации антропологическая природа религиозных коммуникаций связана со способностью субъекта включиться в сам процесс, задействовать непосредственные эмоциональные состояния и реакции воспринимающего. Богатство используемых сенсорных сигналов - жестов, звуков, телодвижений, 
интонаций и др. - придает коммуникативному процессу естественно-непринужденный характер, «от сердца к сердцу», где попытка учесть многообразие символических средств (внесение поправок, дифференциация темпоритма и тональности, выражения лица и глаз) предвосхищает недопонимание и возможные конфликтные моменты.

Следовательно, техницизм как внутренняя пружина развития современного общества микширует общий взгляд на природу общения, накладывает отпечаток на осознание субъектами Божественного начала. Антропологизация, напротив, удерживает канонические формы религиозной коммуникативности.

4. Противоречие между формами электронного коммуничирования и формами "реального " религиозного общения.

При всей видимости этого противоречия оно дополняет предыдущее, обогащая коммуникативный процесс. Следует отметить, что электронная коммуникация, возникшая менее полувека назад, в дискурсе рассматривается как функциональная разновидность языка, предназначенного для реализации характерных коммуникативных целей - ради самого общения. Вбирая множественные речевые практики и специфические характеристики, электронная коммуникация в разных формах (общение по электронной почте и в чатах, социальных сетях, блогах, мобильных приложениях) преуменьшает значимость человека в сравнении с технологиями. Кроме того, возможны коммуникативные барьеры, связанные с естественными или техническими помехами в коммуникационных каналах.

Между тем стягивание мира в единую целостность превращает глобальную сеть также и в средство отправления квазирелигиозных обрядов. Это можно наблюдать, к примеру, в США, где получили распространение такие противоречивые формы практической электронной коммуникации, как «виртуальная молитва вдвоем с пастырем», «виртуальная исповедь», «виртуальное причащение» (верующие вкушают собственные хлеб и вино), «онлайн-крещение» и др. ${ }^{4}$ Отдаляя субъектов религиозных обрядов друг от друга, электронное коммуницирование задействует посредника - специалиста информационных технологий, обеспечивающего интерактивность религиозного действа в online-режиме.

Здесь можно вести речь о разной спектральной насыщенности форм электронного и «живого» религиозного общения. В первом случае - это дискурс, монолог, диалог, полилог; во втором случае - переговоры, приходские собрания, дискуссия, полемика, индивидуальная и групповая беседа с пастырем. Палитра последних существенно богаче за счет эмоционально-чувственной составляющей субъектов: дружба, любовь, альтруизм, сопереживание, безразличие, конформизм, негативизм, неприязнь к другим, молчание и др. Неслучайно в российских регионах получает распространение феномен приходского консультирования как форма служения мирян, опекающих посетителей храма или начинающих прихожан ${ }^{5}$. Общение с ними, не подменяя участия в таинствах и душеспасительных бесед со священником, способствует адаптации личности в «неизвестном» духовном пространстве.

Следовательно, существующие в современном мире разновидности коммуникации - электронная и «реальная» - дополняют друг друга. Первая - усваивает невербалику через графические средства выражения (смайлики, эмотиконы и др.), вторая - заимствует из медийного пространства репортажный режим общения, превалирование в устной речи коротких фраз. Религиозные организации и отдельные священнослужители используют обе формы коммуникации. Формы электрон- 
ной коммуникации способствуют наращиванию социальных сетей и привлечению в религиозные общины новых членов; формы «реального», непосредственного общения позволяют персонализировать коммуникативный процесс, сосредоточивать внимание на каждом конкретном человеке, его духовных проблемах. В этом можно обнаружить диалектику развития коммуникативного процесса.

\section{ЗАКАЮЧЕНИЕ}

В условиях глобализации, когда мир видоизменяется, фиксируя и разрешая многие противоречия, религиозные коммуникации отражают это «становление» (Г. Гегель) духовного бытия, поиск универсального языка общения, некоего «медиума коммуникации».

Сущностные противоречия (между глобальным сближением культур, провозглашаемой нетерпимостью к конфликтам на разных уровнях и несовместимостью доктринальных воззрений представителей разных конфессий; между христианским экуменизмом и дифференциацией духовной жизни сообществ) демонстрируют момент их сохранения, что подчеркивает структурные коллизии и инаковость конфессий. Насущным становится переход от конфликта к конструктивной встрече и взаимопониманию. Выступая фундаментальной константой человеческих сообществ, религия превращается в аттрактор глобального миропорядка и развивается «поверх границ».

Акцидентные противоречия (между императивностью библейских норм, традиционных церковных установлений и современными практиками повседневной культуры; между (нео)языческими рудиментами и православием как системой) высвечивают возможность дискурсивных течений в устоявшихся религиозных убеждениях. Следование традиции проецируется на освоение Церковью новых «коммуникативных ниш». Использование социальных сетей и информационно-коммуникационных технологий в определенном смысле трансформирует формообразующее обрамление религиозной коммуникации.

Специфические противоречия (между динамичностью религиозных коммуникаций и установкой на религиозную каноничность; между массовидной природой Божественной литургии, ее индивидуальной перцепцией и апперцепцией; между технологичностью «гаджетовой» религиозной коммуникативности и антропологической природой общения; между формами электронного коммуницирования и формами «реального» религиозного общения) обозначают метаморфозу системы религиозных коммуникаций, перестройку ее средств. Смена стадии технологического развития, изменившая мировосприятие личности и образ жизни в целом, инициировала диверсифицированность коммуникативных стратегий Церкви. Ограниченный информационный локус Русской Православной Церкви сменился ее широкоформатным позиционированием в социокультурном пространстве.

В условиях глобализационных реалий парадоксальность, традиционность, технологичность религиозных коммуникаций становится все более явной и отчетливой.

\section{ПРИМЕЧАНИЯ}

1 Внутренняя жизнь и внешняя деятельность Русской Православной Церкви с 2009 года по 2019 год (2019) [Электронный ресурс]// Русская Православная Церковь. URL: http://www.patriarchia.ru/db/text/5359105.html (дата обращения: 01.03.2019).

2 URL: http://globus.aquaviva.ru/ 
3 Глава Русской Православной Церкви предостерег от чрезмерного использования гаджетов (2019) [Электронный ресурс] // Фильмы, книги, музыка. URL: https://www.invictory.org/ news/church/15214-glava-russkoj-pravoslavnoj-tserkvi-predostereg-ot-chrezmernogo-ispolzovaniya-gadzhetov (дата обращения: 05.02.2019).

4 Интернет-верующие: пасторы открывают онлайн-церкви (2018) [Электронный ресурс] // Агентство религиозной информации «Благовест-Инфо».URL: http://www.blagovest.info.ru/index.php?ss=2\&s=7\&id=30672 (дата обращения: 12.09.2018).

5 Внутренняя жизнь и внешняя деятельность Русской Православной Церкви ..., 2019: Электронный ресурс.

\section{СПИСОК АИТЕРАТУРЫ}

Абдулатипов, Р. Г. (2012) Человек и культура. Философия и практика духовных идеалов. М. : МГУКИ. 188 с.

Амельченков, В. А. (2015) Религиозный фактор в развитии польско-российских культурных связей // Россия и Запад: диалог культур. Т. 2. №17. С. 28-38.

Бахтин, М. М. (1975) Вопросы литературы и эстетики. М. : Художественная литература. 502 с.

Булгаков, С. Н., прот. (2018) Церковь и культура // Церковь и культура: пути взаимодействия: статьи, выступления, интервью / протоиерей Сергий Булгаков; священник Павел Флоренский; священник Георгий Кочетков. М. : Преображение. 101 с. С. 5-14.

Григорий, иером. (Святая Гора Афон) (2001) Аитургия Божественной Евхаристии: Божественная Евхаристия по святому Иоанну Златоусту. Клин : Фонд «Христианская жизнь». 96 с.

Гриненко, Г. В. (2000) Иогико-семиотический анализ сакральных текстов и сакральной коммуникации : автореф. дис. ... А-ра филос. наук. М. 37 с.

Жуковский, В. И., Пивоваров, А. В., Копцева, Н. П. (2006) Визуальная сущность религии. Красноярск : КрасГУ. 460 с.

Ильин, И. А. (2002) Аксиомы религиозного опыта. М. : АСТ. 588 с.

Ирхен, И. И. (2014) Сближение культур и его культурологические смыслы // Вестник Костромского государственного университета им. Н. А. Некрасова. № 7. Т. 20. С. 253-256.

Костина, А. В. (2011) Аиалог в современном мире: условия и возможности осуществления // Знание. Понимание. Умение. № 3. С. 9-20.

Межуев, В. М. (2012) Идея культуры. Очерки по философии культуры. М. : Университетская книга. 406 с.

Панарин, А. С. (2002) Православная цивилизация в глобальном мире. М. : Алгоритм. 496 с.

Ремизов, В. А. (1997) Ауховность как культурная ценность личности // Философские науки. № 2. C. 158-161.

Ремизов, В. А. (2017) Синусоидность трансформаций в коммуникативной культуре: эпизодность или тенденция? // Вестник Московского государственного университета культуры и искусств. № 5. С. 62-68.

Сапунов, Б. М. (2006) Введение в культурологию. Основы медиакультуры. М. :ИПКРТиР. $68 \mathrm{c}$.

Флоренский, П. А., свящ. (2004) Философия культа (Опыт православной антроподицеи). М. : Мысль. 685 с.

Франкл, В. (1990) Человек в поисках смысла. М. : Прогресс. 366 с.

Biskup Serafin (Amielczenkow) (2019). Polski i rosyjski wymiar duszpasterstwa świętego mẹczennika Serafina (Ostroumowa), arcybiskupa smoleńskiego. Warszawa : Warszawska Metropolia Prawoslawna. $334 \mathrm{~s}$.

Kurzweil, R. (1999) The age of Spiritual Machines. NewYork : VikingPress. 400 p.

Robertson, R., Chirico, J. (1985) Humanity, Globalization and Worldwide Religious Resurgence: a Theoretical Exploration // Sociological Analysis. Vol. 46 (3). P. 219-242. 


\section{THE MODERN WORLD AND THE CONTRADICTIONS \\ OF RELIGIOUS COMMUNICATIVENESS \\ V. L. AMELCHENKOV (BISHOP SERAPHIM) \\ SyNOdAL YOUTH DEPARTMENT OF THE RUSSIAN ORTHODOX CHURCH; \\ RUSSIAN STATE SOCIAL UNIVERSITY}

This paper addresses the issues of religious communications as a case of cultural communication whose level affects a special area of confessional practice. The aim of the study is to present religious communication as a system bringing up to date the controversial unity ofitscomponentsin a global world. The paper identifies the following groups of contradictions of religious communications: essential, incidental, specific.Essential contradictions demonstrate the moment of their preservation, which emphasizes structural conflicts and rivalries of denominations. The transition from "collision" to a constructive meeting and the mutual understanding becomes urgent. Accidental controversy highlights the possibility of discursive processes in the settled religious beliefs. The use of social media and information and communication technologies transforms the formative frame of religious communication. The specific contradictions mean the metamorphosis of the religious communications system, the restructuring of its means. The change of the technological development phase initiated the diversification of communication strategies of the church. The limited information locus of the Russian Orthodox Church gave way to its wide-format positioning in the socio-cultural space.

Keywords: culture; religion; church; communicative culture; religious communication

\section{REFERENCES}

Abdulatipov, R. G. (2012) Chelovek i kul'tura. Filosofiia $i$ praktika dukbovnykb idealov. Moscow, MGUKI. 188 p. (In Russ.).

Amel'chenkov, V. L. (2015) Religioznyi faktor v razvitii pol'sko-rossiiskikh kul'turnykh sviazei. Rossiia i Zapad: dialog kul'tur, vol. 2, no. 17, pp. 28-38. (In Russ.).

Bakhtin, M. M. (1975) Voprosy literatury i estetiki. Moscow, Khudozhestvennaia literatura. 502 p. (In Russ.).

Bulgakov, S. N., prot. (2018) Tserkov' i kul'tura. In: Tserkov' i kul'tura: puti vzaimodeistviia: stat'i, vystupleniia, interv'iu / protoierei Sergii Bulgakov; sviashchennik Pavel Florenskii; sviashchennik Georgii Kochetkov. Moscow, Preobrazhenie. 101 p. Pp. 5-14.(In Russ.).

Grigorii, ierom. (Sviataia Gora Afon) (2001) Liturgiia Bozhestvennoi Evkharistii: Bozhestvennaia Evkharistiia po sviatomu Ioannu Zlatoustu. Klin, Fond «Khristianskaia zhizn’». 96 p. (In Russ.).

Grinenko, G. V. (2000) Logiko-semioticheskii analiz sakral'nykb tekstov i sakral' noi kommunikatsii: Thesis of Diss. ... Doctor of Philosophy. Moscow. 37 p.(In Russ.).

Zhukovskii, V. I., Pivovarov, D. V. and Koptseva, N. P. (2006) Vizual'naia sushchnost' religii. Krasnoiarsk, KrasGU. 460 p. (In Russ.).

Il'in, I. A. (2002) Aksiomy religioznogo opyta. Moscow, AST. 588 p. (In Russ.).

Irkhen, I. I. (2014) Sblizhenie kul'tur i ego kul'turologicheskie smysly. Vestnik Kostromskogo gosudarstvennogo universiteta im. N. A. Nekrasova, no. 7, vol. 20, pp. 253-256.(In Russ.).

Kostina, A. V. (2011) Dialog v sovremennom mire: usloviia i vozmozhnosti osushchestvleniia. Znanie. Ponimanie. Umenie, no. 3, pp. 9-20. (In Russ.).

Mezhuev, V. M. (2012) Ideia kul'tury. Ocherki po filosofii kul'tury. Moscow, Universitetskaia kniga. 406 p. (In Russ.).

Panarin, A. S. (2002) Pravoslavnaia tsivilizatsiia v global'nom mire. Moscow, Algoritm. 496 p. (In Russ.).

Remizov, V. A. (1997) Dukhovnost' kak kul'turnaia tsennost' lichnosti. Filosofskie nauki, no. 2, pp. 158-161. (In Russ.).

Remizov, V. A. (2017) Sinusoidnost' transformatsii v kommunikativnoi kul'ture: epizodnost' ili tendentsiia? Vestnik Moskovskogo gosudarstvennogo universiteta kul'tury i iskusstv, no. 5, pp. 62-68. (In Russ.). 
Sapunov, B. M. (2006) Vvedenie v kul'turologiiu. Osnovy mediakul'tury. Moscow, IPKRTiR. 68 p. (In Russ.).

Florenskii, P. A., sviashch. (2004) Filosofiia kul'ta (Opyt pravoslavnoi antropoditsei). Moscow, Mysl'. 685 p. (In Russ.).

Frankl, V. (1990) Chelovek v poiskakb smysla. Moscow, Progress. 366 p. (In Russ.).

Biskup Serafin (Amielczenkow) (2019). Polski i rosyjski wymiar duszpasterstwa świętego meczennika Serafina (Ostroumowa), arcybiskupa smoleniskiego. Warszawa, Warszawska Metropolia Prawoslawna. 334 p. (In Pol.)

Kurzweil, R. (1999) The age of Spiritual Machines. New York, Viking Press. 400 p.

Robertson, R. and Chirico, J. (1985) Humanity, Globalization and Worldwide Religious Resurgence: a Theoretical Exploration. Sociological Analysis, vol. 46 (3), p. 219-242.

Submissiondate: 12.02 .2020$.

Амельченков Владимир Аеонидович (епископ Истринский Серафим) - доктор теологии, кандидат исторических наук, доцент, председатель Синодального отдела по делам молодежи Русской Православной Церкви; заведующий кафедрой истории религии, мировых культур и теологии Российского государственного социального университета. Адрес: 109044, Россия, г. Москва, ул. Крутицкая, А. 17 с7 (Крутицкое Патриаршее подворье). Тел.: +7 (495) 671-77-23. Эл. aspec: seraphim@list.ru

Amelchenkov Vladimir Leonidovich (Bishop Seraphim of Istra), Doctorof Theology, Candidate of History, Associate Professor, Chairman, Synodal Youth Department of the Russian Orthodox Church; Head, Department of History of Religion, World Cultures and Theology, Russian State Social University. Postal address: 17, Bldg. 7, Krutyskaya St., (Krutysy Patriarchal Metochion), Moscow, Russian Federation, 109044. Tel.: +7 (495) 671-77-23. E-mail: seraphim@list.ru 